\title{
A LÉZERVÁGÁS BIZTONSÁGTECHNIKAI KÉRDÉSEI
}

\section{THE SAFETY ISSUES OF LASER CUTTING}

\author{
Andraws Andrew ${ }^{1}$, Kovács-Coskun Tünde ${ }^{2}$ \\ Óbudai Egyetem, Bánki Donát Gépész és Biztonságtechnikai Mérnöki Kar, Cím: \\ 1034 Magyarország Budapest, Bécsi út 96/B. \\ Itigris9494@hotmail.com \\ ${ }^{2}$ kovacs.tunde@bgk.uni-obuda.hu
}

\begin{abstract}
In this writting we are examining the effect of laser beam on living organisms. As we all know laser is dangerous to living organisms even though we use it in multiple usefull technologies. That's why we have to take into consideration its dangers and take equal actions in making safety rules that reduces the amount of injuries occurring while using lasers.
\end{abstract}

Keywords: safety, safety rules, laser safety, laser.

\section{Összefoglalás}

Ebben a cikkben a termikus vágásnál is alkalmazott lézersugár élő szervezetre való hatását vizsgáljuk. A lézer veszélyes az élő szervezetekre nézve, ennek ellenére több hasznos technológiában használjuk. Figyelembe kell vennünk a lézer technológia veszélyeit és megfelelő biztonsági szabályokat kell foganatosítani a lézer okozta sérülések csökkentésére.

Kulcsszavak: biztonság, biztonsági elöírások, lézer biztonság, lézer.

\section{A Lézer}

A lézer szó az angol LASER szóból származik mozaikszó (Light Amplification by the Stimulated Emission of Radiation, ami magyarul fényerősítés a sugárzás indukált emissziójával). A lézer müködéséhez tehát az szükséges, hogy domináljon az indukált emisszió, és a fény általa erősödjön. [1]

Az első lézert az amerikai Maiman fejlesztette ki 1960-ban. A prototípus anyaga, amelyben a lézereffektus lejátszódott, rubinkristály $\left(\mathrm{Cr}_{2} \mathrm{O}_{3}\right.$-mal szennyezett $\mathrm{Al}_{2} \mathrm{O}_{3}$ kristály, amely rendelkezik a megfelelő metastabil energiaszinttel) volt, gerjesztésként pedig egy villanólámpa fényét használ- ta. A rubinkristály két végére féligáteresztő, illetve egy nagy visszaverő-képességü tükörréteget párologtattak (1. ábra).

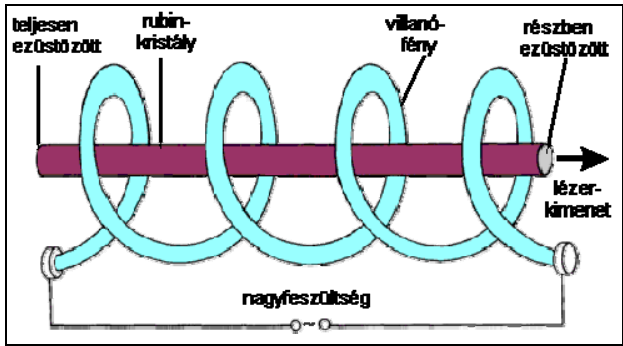

1. ábra. Rubinlézer vázlata [1] 
Amikor a villanólámpa gerjeszti a rubint, és létrejön az a nagyon jól meghatározott energiájú (a metastabil állapot és az alapállapot különbségének megfelelő) fény, amely a lézerfény kibocsátását elindítja, az először a kristály két végéről sokszor viszszaverődve ide-oda cikázik a kristály tengelye mentén. Mivel a rubin oldalán nincsen tükör, a többszöri visszaverődés miatt csak azok a sugarak maradnak meg a rendszerben, amelyek szigorúan párhuzamosak a kristály hossztengelyével.

Amikor a fény energiája meghaladja azt a mértéket, amely már ki tud lépni a féligáteresztö tükrön, a lézer világítani kezd. A két tükör, vagyis voltaképpen az elrendezés geometriája miatt a kilépő fény már nagyon párhuzamos nyalábokból áll, a sugár széttartása (divergenciája) elhanyagolhatóan kicsi [2].

\section{Lézervágás elve}

Nagy energiasürüségről vagy nagy teljesítménysürüségről akkor szokás beszélni, ha a fajlagos teljesítmény- (energia-) bevitel meghaladja a $102 \mathrm{~W} / \mathrm{mm} 2=104 \mathrm{~W} / \mathrm{cm} 2=$ 108W/m2-es értéket. Ez a határérték azonban nem különíti el jól és egyértelmüen a hagyományos, illetve az általában nagy energiasürüségüként említett vagy ismert hőforrásokat. Ezeket a hőforrásokat az anyagtechnológiák több területén (pl.vágás, felületkezelés) is alkalmazzák [7].

Anyagszétválasztás az alapanyag lézersugárral való ömlesztésével. Az ömledéket gázsugár fújja ki (2. ábra).

Ömlesztő és gőzölögtető lézervágásnál a lézersugár helyileg megolvasztja a vágandó anyagot, a keletkezett ömledéket, aktív vagy semleges gázsugár fújja ki, vagy az ömledék elgőzölög.

Oxidáló lézervágás a lángvágásra alkalmas alapanyag lézersugárral való felhevítése és oxigénsugárban való elégetése. A keletkező salakot az oxigénsugár a vágási résből kifújja [7, 8]. A biztonságtechnikai ismeretek birtokában lehet elérni, hogy a „problémamegoldó” lézer ne okozzon egészséget veszélyeztető problémákat [7].

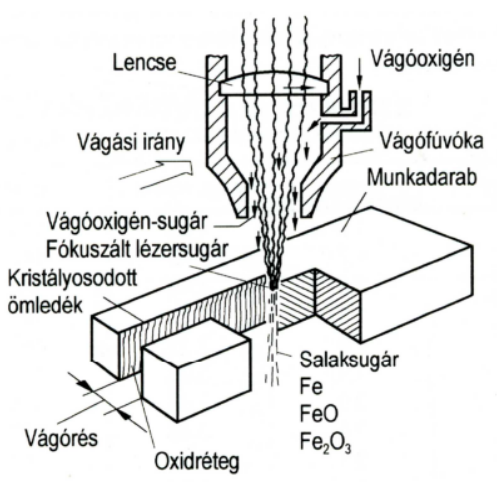

2. ábra. Lézervágás elrendezése [8].

\section{Lézersugár élő szervezetre való hatása}

A lézerforrást tartalmazó berendezések egyre elterjedtebbek a héköznapi életben. Az ipari lézerberendezések esetében igen nagy figyelmet kell fordítanunk a biztonságtechnikára. A lézerberendezéseket használó munkahelyen egészséget károsító sugárzás érheti az ott dolgozókat, ezért biztonsági elöírásokat szabvány rögzíti, az előírások betartását pedig törvény írja elö. A lézergyártmányok sugárbiztonsági előírásait több szabványban is megtaláljuk és csak ezen szabványok előírásait alkalmazhatjuk.

A nemzetközi szabvány 1-4 osztályba sorolja az eszközöket. Ezeken belül található még egy-egy karakterrel megkülönböztetett felosztás. Mindezek alapja az élettani hatás. A szabvány az alábbiakat különbözteti meg: 1, 1M, 2, 2M, 3R, 3B és 4 .

\subsection{1-es osztályú lézerberendezés}

Azokat a veszélytelen lézereszközöket soroljuk ide, amelyeknél az előállított lézernyaláb teljesítménye mindig alatta marad 
a legnagyobb megengedett expozíció értékének, pl. a 3. ábrán látható $\mathrm{CD}$ olvasót.

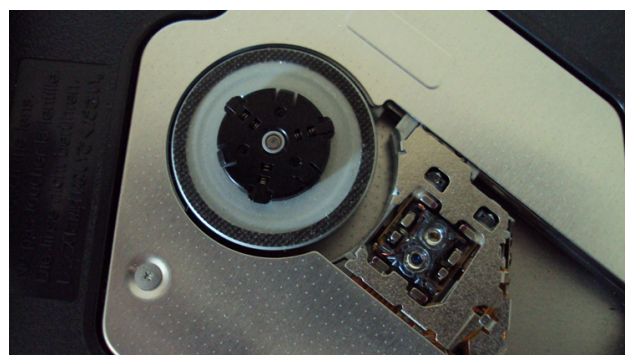

3. ábra. 1-es osztályú CD olvasó

\subsection{M-es osztályú lézerberendezés}

A 302,5-től $4.000 \mathrm{~nm}$-ig terjedő hullámhosszúságú lézersugarakat alkalmazzák. Az emberi szemre nem veszélyesek, kivéve, azt ha a sugárzás a keresztmetszetét csökkentő optikai eszközből érkezik.

\subsection{2-es osztályú lézerberendezés}

Ez az osztály a 400-700 nm hullámhossztartományban müködő lézerekre (4. ábra) vonatkozik. A rövididejü $(\mathrm{t}<0,25$ s) besugárzás esetén az emberi szemre sem veszélyes. A 400-700 nm tartományon kívüli sugárzásokra az 1-es lézerosztály elöírásai érvényesek.

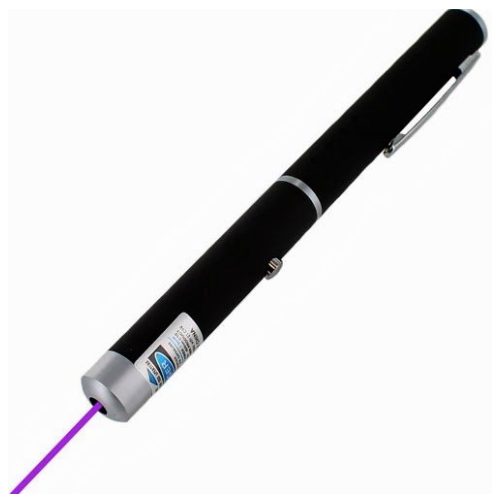

4. ábra. Pointer. Nagyobb kivitelben elérheti az $3 A$ besorolást is [3].

\subsection{M-es osztályú lézerberendezés}

Ez az osztály a 400-700 nm hullámhossztartományban müködő lézerekre vonatkozik. A rövididejü $(\mathrm{t}<0,25 \mathrm{~s})$ besugárzás esetén az emberi szemre nem veszélyes, kivéve, ha az a sugárzás keresztmetszetét csökkentő optikai eszközből érkezik. A 400-700 nm tartományon kívüli sugárzásokra az 1-es lézerosztály elöírásai érvényesek.

\subsection{R osztályú lézerberendezés}

Ebbe az osztályba a 400-700 nm hullámhossztartományban múködő lézerek tartoznak és a rövididejü $(\mathrm{t}<0,25 \mathrm{~s})$ besugárzás esetén az emberi szemre nem veszélyesek, kivéve, ha a sugárzás a keresztmetszetét csökkentő optikai eszközből érkezik. Ekkora sugárzási szintek még a fénytávközlésben is elöfordulnak [4,5].

\subsection{B osztályú lézerberendezés}

Az ilyen eszközök folytonos üzemben legfeljebb $0,5 \mathrm{~W}$ teljesítményt bocsáthatnak ki. Az ilyen nyalábba való nézés mindig veszélyes.

\subsection{4-es osztályú lézerberendezés}

$\mathrm{Az}$ ide sorolt berendezések teljesítménye meghaladja a 3B osztályú eszközökre megengedett határértékeket. Ilyen teljesítmény már bőrkárosodást és tüzet is okozhat. A szórt visszaverődés is káros a szemre.

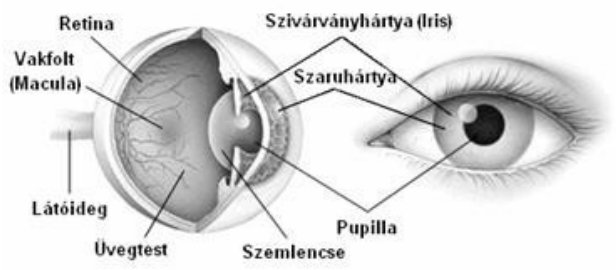

5. ábra. A szem felépitése [3]

A lézersugarak az emberi szemre (5. ábra) a legveszélyesebbek. A szem egyes részeinek eltérő optikai tulajdonságai vannak. 


\section{A fényhullámok hatásai a test különböző részein}

- UVC (100 - $280 \mathrm{~nm}) \rightarrow$ erős abszorpció a felszíni hámrétegben (6. ábra);

- UVB (280 - $315 \mathrm{~nm}) \rightarrow$ börpír, a kapilláris erek kitágulása miatt; határérték $\sim 0,1 \mathrm{~J} / \mathrm{cm}^{2}$;

- UVA $(315$ - $380 \mathrm{~nm}) \rightarrow$ a bör direkt pigmentesedése; határérték $\sim 10 \mathrm{~J} / \mathrm{cm}^{2}$;

- Látható $(380$ - 780) $\rightarrow$ legnagyobb behatoló képesség, fotokémiai reakciók, hőhatások;

- IRA (780 - $1400 \mathrm{~nm})$ és IRB (1400 $3000 \mathrm{~nm}) \rightarrow$ csökkenő behatolási mélység, erős hőhatás;

- IRC (3000 nm - $1 \mathrm{~mm}) \rightarrow$ elnyelődés a bőrfelszínen, erős hőhatás, égés.

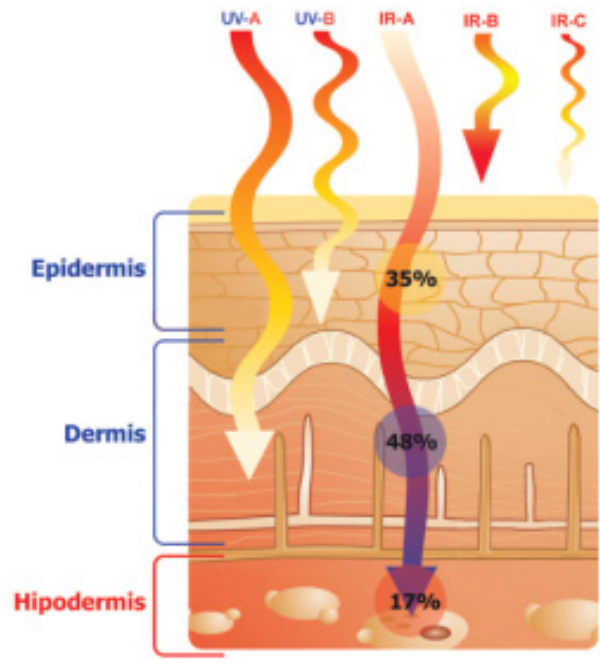

6. ábra. Különbözö fényhullámok behatolása a börbe.

A problémát az jelenti, hogy a szem a látható és a közeli infravörös (IR A; NIR) sugárzást a retinára fókuszálja, emiatt nő a sugárzás intenzitása és sürüsége. A látóidegek a retinánál rendkívül kis keresztmetszetủ vérerekkel vannak behálózva, ami miatt rendkívül sérülékeny lehet pl. a hemoglobin vagy más fehérjéknél a koagulációját vált- hatja ki és mivel ez a hőhatás (az energia elnyelődés miatt) rendhagyóan magas ezért visszafordíthatatlan ez a koaguláció $[3,6]$.

\section{Következtetések}

A lézer nagyon veszélyes a testre és föképpen a szemre, ezért a lézer használat (vágásnál is) a nemzetközi szabványban előirtak szerint kell védekezni a sérülések elkerülése érdekében. A védő szemüveg használata kötelező a 2-es osztálynál nagyobb osztályú lézer berendezések üzemelése közben így a lézervágási technológia alkalmazása során is.

\section{Szakirodalmi hivatkozások}

[1] Paripás Béla: A lézerek müködési elve, indukált emisszió, populációinverzió, http://www.uni-

miskolc.hu/ www_fiz/paripas/diagn/1\%E9zer ek_diagn_14.pdf 2015.04.04

[2] Bitay Enikő: Lézeres felületkezelés és modellezés, Erdélyi Múzeum-Egyesület, Kolozsvár, 2007.

[3] http://www.trumpf-laser.com/ 2015.04.04

[4] Buza Gábor: Lézersugaras technológiák I, EDUTUS 2012.08.22.

[5] Tu J.F., Paleocrassas A.G.: Fatigue crack fusion in thin-sheet aluminium alloys AA075T6 using low-speed fiber laser welding, Journal of Materials Processing Technologie, 2010.

[6] Nemzetközi szabvány IEC 60825-1

[7] Bitay E., Bagyinszki Gy.: A lézeres anyagmegmunkálás veszélyessége, FMTÜ XVIII.. Kolozsvár, 2013.

[8] Gáti József: Hegesztési Zsebkönyv, Cokom mérnökiroda Kft., Miskolc, 2010. 